DOI:

\title{
A new paradigm of development as a modern challenge in agriculture ${ }^{\prime}$
}

Prof. Andrzej Czyżewski, Full Professor

Poznan University of Economics Head of the Department of Macro and Agricultural Economics

Ph.D. Bazyli Czyżewski, Associate Professor

Poznan University of Economics Department of Education and Personnel Development

\section{Introduction}

Contemporary challenges of the agriculture are integrally bound with the negation of neo-classical economics assumptions which were so far present in agricultural economy (Woś, Tomczak 1983). A further ignorance of the role of environment in providing the materials, resources, services and waste disposal, which can be observed in agricultural economics, even make it impossible to run an economic activity and assuming that people aiming at achieving their personal interests inevitably lead to a general good is a counterfactual assumption. Those entities that are oriented towards the maximisation of the profit demonstrate a strong tendency of environmental costs externality, which not always can be expressed in agricultural economics in monetary categories (Tietenberg 2006, Solow 1974, Daly 2007). Therefore the dilemma of the new agricultural (agrarian) economy is the necessity of

1 This paper uses the excerpts of the authors' speech entitled: "The land and its rents in a new paradigm of agricultural development" which was presented on the IX Congress of Polish Economists in November 2013. 
a relative limitation of production effectiveness (and efficiency) of industrial development model (Wojtyna 2008) to the benefit of a life quality improvement within the framework of economically, socially and environmentally balanced new paradigm of management (Zegar 2012). It requires a full acknowledgement of social and environmental costs of production and rejection of the rules which lead to degradation and reduction of natural resources. The above prerequisites describe the need to abandon the current "industrial" agricultural economics and head for a new economic order in which the boundaries of growth are determined by the ecosystem in the conditions of balanced scale of production, then through the specified rules and instruments a required distribution of resources is defined. Its implementation is entrusted to the market mechanism to achieve an efficient allocation (Zegar 2012). In this way, a new agrarian economics take into account the optimal relations of the scale of production and the needs of the natural environment which could guarantee an ecological permanence of managing process, and the natural resources would not be treated equally with the anthropogenic capital. Such an understanding of the ideas of full inputs and effects flows will allow to determine whether the abilities of recovery of particular ecosystem are exceeded. In other words, as J. St. Zegar (2012) enquires, is the marginal utility of growth smaller or bigger than the scale of opportunity costs? However, a problem with the new paradigm of agricultural economy consists in the fact that it assigns an independent value to the natural capital, which exceeds the scope of classical understanding of land rents (Czyżewski B. 2010). A glance of agricultural economics on economic processes only through the view of capital and labour is insufficient (Woś, Zegar 2002, 2002). Since the assumption of natural resources being inexhaustible and global ecosystem being infinite is unacceptable. Nowadays, its contradiction to reality is obvious. While ignoring the significance of land factor, as it takes place for instance in the power functions (i.e. Cobb-Douglas function), is acceptable only as an intellectual exercise and not as business practice. Since this factor determines a lot of public goods and services without which a modern man cannot do without. Therefore the estimation of their demand according to non-commercial (projected) prices will soon become a necessity. It will allow to oppose the market competitiveness against social competitiveness which emphasises the discrepancies between the micro- and macroeconomic criterion. 


\section{An industrial development model of agriculture versus a paradigm of sustainable agriculture}

A market mechanism based on three properties and supply-demand regulations creates the demand for money via prices (Wilkin 1995). In a real sphere it means the concentration of production due to a decrease of its unit cost and the pressure of increasing efficiency of labour as a condition to obtain the competitive advantage (Hayami, Ruttan 1985). In respect of agriculture it means the increase of the production of agricultural resources in conditions of a growing pressure on the natural environment. Providing the food safety for the consumers requires not only the growth of the food supply but also the drop in prices of agricultural resources. This, in turn, negatively influenced the farmer's incomes. If they produced more of cheaper food they gained the incomes significantly lower than the average for non-agricultural households (Schulz 1964, 1968). However, due to the immobility of the basic production factor, which is land, and non-portability (massiveness) of invested assets in farms, they were not able to allocate Pareto-efficiently and at the same time to use efficiently the substitution of production factors (Czyżewski 2003). Therefore, the only possibility was to increase the efficiency of labour in condition of dropping prices of purchase. This, in turn, required a progress of production technologies, including: machines, appliances, innovations, in other words a constant modernisation of farms. This specific dictatorship of efficiency pressure and modernisation of farms did not include full costs of production processes. Unfortunately balancing such unfavourable factors of production as: soil impoverishment, the deterioration of water rate, the production of carbon dioxide, the eutrofication of currents and water reservoirs, soil stepping, did not take place. The environmental welfare with its balance scarcity was not estimated, thus the need to internationalise the costs was not declared. The above described "technological treadmill" was triumphant (Thirtle et al. 2004, Cochran 1958, 1979, Czyżewski 2013). Moreover, it was accompanied by another mechanism of economic depreciation of farms. Soon, it appeared that despite the growth of the incurred modernisation expenses as well as using new technologies and technical progress, the ratio of a standard economic surplus in the price of the product was decreasing. Since on the market there was a concentration of purchase, processing and sales. As a result, bigger and bigger processing and trade corporations appeared which by competing between one another gained the consumers via lower prices (Zegar 2012). In this way, the assumption that a relatively bigger turnover of goods would bring such a large profit that its minimization in the unit price of

A new paradigm of development as a modern challenge in agriculture 
the product will not become an obstacle for the completion of processing and agricultural turnover, was realized. The paradigm of industrial agriculture based on the above described mechanism was accompanied by the unreliability of the market which stimulated the development of the oligopoly and monopoly structures in the relations of the supplier and the recipient. As a result, this model of agricultural development did not come up to two basic targets of modern farming - firstly, it was not able to secure the farmers with a parity of agricultural incomes, limiting the produced economic surplus in the inside and cross-sectoral cash flows (Czyżewski A. 2009; Czyżewski B. 2009), secondly, along with the increase of the scale of industrial agricultural production, to a bigger extent it depreciated the environmental conditions but it did not internalize the external costs of agricultural production (Zegar 2004). The environmental welfare and its ecological balance was breached more and more. It is also important to emphasise that in those conditions the transfer of the economic surplus was present from the agriculture, via a purchasing agent, a processor, the link in the chain of sale, finally to the consumer, while its retransfer back to the agriculture was risky if not secured by modern interventionism of the state. The need of the retransfer of an economic surplus achieved in farming from consumers to farmers became a main priority (Czyżewski 2007). The experience of the Common Agricultural Policy (CAP) of the European Union shows that the reimbursement of that surplus (via the support of market prices) significantly destabilises the market. Hence, as a result of the rules and CAP instruments evolution it was determined that the interventionism, via the instruments which are appropriate to realise the agricultural policy, will act from consumers, through the budget to farmers, omitting the market exchange mechanism to the extent possible. Contemporary empirical research of individual farms (according to Central Statistical Office $\mathrm{CSO}$ ) prove that per account balance in different conditions of economic cycle approximately $10 \%$ of the economic surplus goes from the farmer to other sectors (Czyżewski B. 2013; Czyżewski B., Mrówczyńska-Kamińska 2011) only because of the unreliability of the market mechanism (the flexibility of agricultural prices). It appeared to be an illusion that the acceleration of industrialisation will solve the historically permanent agrarian issue (Czyżewski 2005; Wilkin 1986), while the engine of industrial farming encountered the environmental barrier which made it unable to exclude the agricultural production process from the natural conditions. It resulted in an intensive use of means of production of industrial origin, an excessive concentration of production and increasing its scale.

Therefore a progressing integration of farms with the agri-business environment requires a new development paradigm, at least due to the need of internationalisation 
of external costs of agricultural production because of the ecosystems inability to recover. It appears that agriculture must be subject to the ecological system supremacy, while the economic system is to be regulated by adequate social solutions. Exceeding the capacity of ecosystem already by $1 / 3$, due to the above mentioned "ecological trace", invalidates completely the sense of the rule currently in force that the nature "as a machine" is worth as much as its significance for the man. Even the increased scientific and technological progress is not able to reverse that statement. The inversion of farming development from industrial to the sustainable model is inevitable in a long term, while imposing ethical and social restraints on the industrial mechanism of the agricultural development becomes a necessity. In the situation of popularisation of the sustainable agriculture paradigm and supply restrains it will be easier to overcome the barrier of the food demand. Obviously its rigidity and restrains will not disappear while its income elasticity will still be low. Nevertheless, adaptation mechanism of agriculture to a larger extent will be focused on the allocation of production factors in accordance with the requirements of natural environment and its welfare. Internalisation of full agricultural production costs in conditions of price increase of agricultural products (along with a smaller supply) will allow to improve the income situation of farms by releasing so-called "income scissors", on one hand excluding farms from market circulation due to the barriers of fixed assets flow (supporting arm), while on the other hand it will be due to the restrain of market depreciation of farms (clamping arm) (Zegar 2004; Bywalec 1995). In the conditions when there is a lack of an automatic compensation mechanism of incomes depreciation in the industrial model of agricultural development, sustainable model is favourable for the farms due to the relation with the market and environment. In no way it declines the role of the market itself, which is indispensable in a microeconomic scale, due to the need of forcing some specific actions of the state (intervention). However, there might be different forms of sustainable agriculture due to connecting its productive function with the multifunctional character of farms, their family character, ecological production, supporting the vitality of rural areas, improving the food quality or its symbiosis with the natural environment.

Questioning the current formula of progress in agriculture is a key premise to formulate a new sustainable paradigm of its development (Krasowicz 2009; Fiedor, Kociszewski 2010; Brouver 2004). Such a clear attitude was already formulated in 2002 in, what now seems to be a fundamental piece of work, "Socially balanced agriculture" (Woś, Zegar 2002). The condition of popularisation of a new model of agricultural development is a social conscience of a global ecosystem restrains (inter alia in respect of water, climate changes, waste) (Zegar 2012), as well as the acknowledgement that for farming development not only the market 
goods are important but also the non-market, non-commercial (public) ones like environment welfare, the harmony of nature and agricultural production, the vitality of rural area etc. (Altieri 1995; Uphoff 2002; Gliessman, Rosemeyer 2010). It is worth noticing that the acknowledgement of those public goods need (Samuelson 1954, 1955) means that modernity of technologies cannot be measured only in economic (market) categories but by a level of the production balance in accordance to natural environment requirements (Kośmicki 2009). Such a model is more complicated than the industrial one and it requires larger knowledge and social involvement, nevertheless it gives the warranty of healthy food of higher quality (Malkina-Pykh, Pykh 2003), the supply more balanced with the demand, as well as of a relatively higher price. A key significance is put to a problem of a proper evaluation of non-market goods.

\section{The concept of a land rent in the sustainable agriculture paradigm}

Since the beginning of the existence of the human civilisation the land creates some benefits which fulfil people's needs. Those are created without the participation of production factors becoming indisputable gifts of nature. In the encyclical "Caritas in Veritate" His Holiness Pope Benedict XVI describes them as "the wonderful result of God's creative activity, which we may use responsibly to satisfy our legitimate needs, material or otherwise, while respecting the intrinsic balance of creation" (to find out more see: Czyżewski, Matuszczak 2012, pp.9-14). In tribal farming (natural) when the agricultural land (in its current meaning) did not exist, the results of the above use were forest fruit, animals hunted, the water access or the firewood. The creative role of the land factor in their making was dominant compared to the labour and capital input which was necessary to obtain them. Therefore it can be stated that the majority of the land utility is created independently. Upon the start of land cultivation and animals domestication the part attributed to the nature diminished insignificantly in favour of the causative role of the human. Nevertheless, the growth of plants and animals, the construction material or widely understood living space, to a big extent were all gained without any inputs.

In the feudal system a specific legitimacy of independent utilities of land can be recognised as "easements" treated as the right to use the natural utility of landowner's property (in the form of brushwood, fruit, clay or fish). As the commodity-monetary trade developed that part of the land utility, which was created without the participation of capital and labour, was transformed into "selfproductivity" (in monetary terms). It is for instance reflected in the $18^{\text {th }}$ century 
conception of pure product presented by Physiocrats. According to that concept the financial surplus over the borne input (capital and labour) can be captured only in agriculture - thanks to the causative role of nature. The pure product in the "Tableau économique" (1758) of F. Quesnay, the former of Physiocrats' School, is a first attempt of valorisation of self-productivity of the land. According to Physiocrats' vision the product could not arise in any other economy sector because all other production factors (apart from land) "demanded" the payment which in conditions of market competitiveness equalled exactly the value of their product. However, the pure product was fully captured by the landowners as a rent, which reflects the essence of land rent.

Therefore in the farming economy the part of utility attributed to an exclusive performance of nature (land) was relatively big and was expressed in some part of monetary productivity of the farm (as it created a part of the product without the input). Its significance started to decrease in the conditions of agriculture industrialisation and activation of the rule of the diminishing marginal utility. In industrial agriculture the independent share of land in creating the utility decreased in favour of capital and wage-labour. Also the monetary selfproductivity of land disappeared significantly.

However, over time the productive functions of agricultural land were assigned to microeconomic optimisation and the pressure of fulfilling the existential needs became competitive to each other. It created the necessity to search for a new concept of economic development - the paradigm of sustainable and permanent development.

One of the premises of that paradigm implementation in the agricultural economics is the fact that the natural environment in highly developed countries became almost fully anthropogenic. In those conditions also the way of using the natural resources must change completely. It is forced by the above described new needs and priorities - i.e. the postulate of the renewability of natural resources, as well as the pro-social and pro-environmental criteria of production factors allocation. They rediscover the land factor "utility" which is marginalised in the industrial agriculture, granting it the character of a public good which should be paid for by the whole society. However, it cannot be the same self-utility of agricultural land as in $18^{\text {th }}$ century because at least in highly developed countries the natural environment was diametrically changed by the man. A bigger and bigger part of the land utility is again created independently but in conditions of extended and irreversible accumulation of capital in welfare of natural resources. Therefore it can be stated that in the sustainable agriculture a lot of new utilities of land factor are created independently, i.e. without 
additional capital and labour inputs (but all in all not without their causative role). For their character is of public goods, then they are mostly paid by the taxes (in the European Union via the CAP programmes) and this fee goes to the owners of the land factor which created them. In this way the self-utility of land takes a form of a monetary product and can be called the "self-productivity" which raises the monetary productivity of processing structures. Summing up, the agricultural land independently creates a part of its utility which is subject to a market or institutional valorisation, provided that it is limited to some intensity level of agricultural economy. This is, however, conditioned by the determined level of "primary" capital accumulation which causes that the economy is at such evolutionary level that the society declares the demand for the above utility.

Along with the development of market economy a different stages of the land rent valorisation can be attached. The first stage of the economy development which is connected with the evolution of social conscience, the market and/ or the appointed institutions valorise the self-utilities of land of the public goods character and grant the monetary status. Within the framework of the paradigm of the sustainable agriculture, the reason of the land rent arising, is the independent utility of land which in the commodity-monetary economy causes that the expected productivity of capital factor in agriculture is higher than its market surrounding. Therefore, the level of the land rent is determined by the difference between the expected capital productivity in agriculture and its market surrounding. The market of the agricultural land realises, in the land prices, the expectations due to the surplus productivity of capital in agriculture. However, in the process of the assessment it ignores the factor of labour of the farmer because that factor has no market value. Among other things this is why the rents achieved by the individual farms in their incomes do not cover the values resulting from the land prices.

This is an alternative concept to classical theories, which finds its justification in modern institutional economy (in the public choice theory). In general, the economists agree on the fact that the market system does not lead to optimal allocation of public goods and common resources. Market conditions inevitably lead to their deficiency or excessive exploitation. The allocation problem in that case is a multiplayer prisoner's dilemma. A free market offers private goods to all the buyers, in different quantities, at the same equilibrium price. However, everybody is provided with public goods in the same quantity but with a different tendency to take part in the making process. Hence, it is postulated to differentiate the tax charge due to the above mentioned share (an example is presented by the Pigovian tax). Economic models show that a mechanism 
similar to a market mechanism can be developed and that this mechanism will enable to determine a socially optimal level of public goods along with the tax prices in line with individual preferences. However, in the process of reaching the equilibrium it is indispensable so that market participants reveal "a sincere" demand on the public good. On the individual level this assumption is unreal but specific institutional solutions can be more effective. CAP mechanisms can be acknowledged as an attempt to reveal the demand on public goods linked with the welfare of rural areas. Thanks to subsidies the agriculture which provides public goods (and consumes less of them on the net basis) pays lower net taxes. The mechanism, however, is not resistant to a strategic manipulation of the assessments made by particular entities, e.g. those farmers which get support but they do not create the required public goods.

\section{Conclusions}

The paradigm of the sustainable agriculture, which describes a new agrarian economics, does not concern the rules of an economic calculation, but a target, range and research method. In the industrial model of development it was a maximisation of an economic surplus in households for the purposes of farms. The productive factors had their market price and the other factors were regarded as free goods. In new agrarian economics there is the integrity of economic, social and environmental aims, while in an economic account the benefits gained and opportunities lost as well as the external effects (negative and positive) must be presented. In the sustainable farming it is present not only in the economic sense but also in a social and ecological one. A need of a new equilibrium emerges but it cannot be created only by the commercial effects of agriculture. Also the food quality, carbon dioxide sequestration, the protection of soil and water, bio-diversity and similar effects is very important. It is worth emphasising, after J. St. Zegar, that as far as economic benefits have specified, definite recipients, then the disadvantages mostly consider all tax-payers, the world of nature and future generations (Zegar 2012).

Proceeding to determinants of sustainable paradigm of agricultural development, the need of external costs account and a new insight into the origins of a land rent come into prominence. Without that evaluation, the competitiveness accounting of agricultural production is carried out at the cost of natural capital. Secondly, the scale of the nature use must be connected with a legal regulation, established by the state under the administrative decisions which concern the quality standards, fees, penalties and subsidies. Some 
instruments of costs internalisation can be included in prices accounts, the other are neutral in relation to prices.

Thirdly, the condition of popularisation of the paradigm of the sustainable agriculture is the institutional factor (national) which describes the division between the private and social rationality in the economic calculation as well as of the public goods. The problem is how to support the market mechanism with the institutional support, since it is the functioning of specific institutions which is to bring to the criterion of microeconomic and social compliance in the process of decision-making of economic entities. Therefore the assumption is made that an efficient state will actually better secure the common goods than the market which is driven by consumers' needs. On the other hand, impairment of the state abilities due to a bad adjustment of institutional factor does not favour the model of sustainable agriculture. The change of agricultural development paradigm from industrial to a sustainable one will be neither easy nor quick. It is necessary to realize the fact that agrarian economics treats agriculture not only as a business but also the manner of living, and it takes time. The economic theory should evolutionally develop into the direction of sustainable development. This process has already started, nevertheless it creates numerous dilemmas. However, it is already obvious that farming must fulfil the demand for the food, diminishing the pressure on environment, taking into consideration the technical and biological progress, the need of food safety and global economic, social and environmental rationality.

\section{Summary}

\section{A new paradigm of development as a modern challenge in agriculture}

The authors of the paper propose a thesis of a necessary change of an industrial development paradigm of agriculture to a socially sustainable one. They present the mechanism of functioning of the first one proving that by stimulating the growth of production of agricultural raw materials it leads to a decreasing marginal productivity and, as a result, to lower incomes of farmers in the conditions of incomplete internalisation of costs. The pressure on natural environment leads to the deterioration of the natural environment welfare. Therefore, the change of that paradigm to the socially sustainable one is necessary. The effects of that model, which exceed the productive and economic sphere, were presented. They take into account the fact that agriculture is also 
a supplier of public goods. In that case a new concept of a land rent was included, assuming that the agricultural land independently creates a part of a land utility which is subject to market or institutional valorisation if it is limited to some extent of intensity of agricultural economics. However, there must be a declaration of a social demand for that utility of a public character. That process has already started and it determines the evolutionary change of the paradigm of the agricultural development.

Key words: industrial and sustainable paradigm of agricultural development, the environment welfare, the agriculture as a public good, a modern land rent.

\section{Streszczenie}

Słowa

kluczowe: industrialny i zrównoważony paradygmat rozwoju rolnictwa, dobrostan środowiska, rolnictwo jako dobro publiczne, współczesna renta gruntowa. 


\section{References}

1. Altieri M.A. (1995), Agroecology: The Science of Sustainable Agriculture, wyd.2, Westview Press, Boulder.

2. Brouwer F. (ed.) (2004), Sustaining Agriculture and the Rural Environment, Edward Elgar, Cheltenham, Northampton.

3. Bywalec Cz. (1995), W pętli paradoksów, „Nowe Życie Gospodarcze”, nr 15.

4. Cochran W.W. (1958), Farm Prices, Myth and Reality, University of Minnesota Press, Minneapolis.

5. Czyżewski B. (2009), Instytucjonalne uwarunkowania zrównoważonego podziatu dochodów w rolnictwie indywidualnym w Polsce, in: J.S. Zegar (ed.), Z badań nad rolnictwem społecznie zrównoważonym, Program Wieloletni 20042009, Raport 174, IERiGŻ, Warszawa.

6. Czyżewski A. (ed.) (2003), Makroekonomiczne problemy agrobiznesu w Polsce w okresie przedakcesyjnym, Wyd. AE w Poznaniu, nr 30, Poznań.

7. Czyżewski A. (2013), O nowy paradygmat rozwoju rolnictwa (refleksje nad ksiażka J. St. Zegara "Wspótczesne wyzwania rolnictwa”, „Ekonomista”, nr 6.

8. Czyżewski A. (ed.) (2007), Uniwersalia polityki rolnej w gospodarce rynkowej. Ujęcie makro- $i$ mikroekonomiczne, Wyd. AE w Poznaniu, Poznań.

9. Czyżewski A., Matuszczak A, (eds.) (2012), Ekonomia ijej społeczne otoczenie, Wyd. Kujawsko-Pomorskiej Szkoły Wyższej w Bydgoszczy, Bydgoszcz.

10. Czyżewski A. (2009), Potrzeba badań makroekonomicznych w gospodarce żywnościowej, „Roczniki Nauk Rolniczych”, nr 2, seria G.

11. Czyżewski A. (2005), Rolnictwo w procesie reprodukcji. Różne wizje dostosowań rynkowych, in: B. Klepacki (ed.), Kwestia agrarna w Polsce i na świecie, Wyd. SGGW, Warszawa.

12. Czyżewski B. (2010), Kontrowersje wokót rent gruntowych: od ekonomii klasycznej do czasów wspótczesnych, „Ekonomista”, nr 2.

13. Czyżewski B., Mrówczyńska-Kamińska A. (2011), Przepływy międzygatęziowe i podziat rent w sektorze rolno-żywnościowym w Polsce w latach 1995-2005, „Ekonomista”, nr 2.

14. Czyżewski B. (2013), Renty ekonomiczne w gospodarce żywnościowej w Polsce, PWE, Warszawa.

15. Daly H. (2007), Ecological Economics and Sustainable Development, Selected Essays of Herman Daly, Edward Elgar, Cheltenham, Northampton.

16. Fiedor B., Kociszewski K. (red.) (2010), Ekonomia rozwoju, Wyd. UE we Wrocławiu, Wrocław.

17. Gliessman S.R., Rosemeyer M. (red.) (2010), The Conversion to Sustainable Agriculture Principles, Processes and Practices, CRL Press, Boca Raton, London, New York.

18. Hayami Y., Ruttan V.W. (1985), Agricultural Development: An Internationale Perspective, The John Hopkins Univ. Press, Baltimore - London. 
19. Kośmicki E. (2009), Główne zagadnienia ekologizacji społeczeństwa i gospodarki, EkoPress, Białystok.

20. Krasowicz S. (2009), W Polsce powinno dominować rolnictwo zrównoważone, in: A. Harasim (ed.), Przyszłość sektora rolno-spożywczego i obszarów wiejskich, I Kongres Nauk Rolniczych, Instytut Uprawy Nawożenia i Gleboznawstwa - Państwowy Instytut Badawczy, Puławy.

21. Malkina-Pykh I.G., Pykh Y.A. (2003), Sustainable Food and Agriculture, WIT Press, Southampton, Boston.

22. Samuelson P. A. (1951), Economics, McGraw-Hill, New York.

23. Samuelson P.A. (1954), The pure theory of public expenditure, "Review of Economics and Statistics" Vol. 11, No. 35.

24. Samuelson P.A. (1955), Diagrammatic Exposition of a Theory of Public Expenditure, "Review of Economics and Statistics", Vol. 11, No. 37.

25. Schultz T.W. (1964), Transforming Traditional Agriculture, Yale University Press, New Haven.

26. Schultz T.W. (1968), Economic Growth and Agriculture, MacGrow-Hill, New York.

27. Smith A. (1954), Badania nad natura i przyczynami bogactwa narodów, PWN, Warszawa.

28. Solow R.M. (1974), The economics of resources or the resources of economics, "American Economic Review", Vol. 40.

29. Thirtle C., Lin L., Holding J., Jenkins L., Piesse I. (2004), Explaining the Decline in UK Agricultural Productivity Growth, "Journal of Agricultural Economics", No. 55 (2).

30. Tietenberg T. (2006), Environmental natural resource economics, wyd.7, Pearson Education, Inc., New York, London.

31. Uphoff N. (ed.) (2002), Agroecological Innovations: Increasing Food Production with Participatory Development, Earthscan Publications Ltd., London.

32. Wilkin J. (1995), Jaki kapitalizm, jaka Polska, PWN, Warszawa.

33. Wilkin J. (1986), Wspótczesna kwestia agrarna, PWN, Warszawa.

34. Wojtyna A. (2008), Wspótczesna ekonomia - kontynuacja czy poszukiwanie nowego paradygmatu, „Ekonomista”, nr 1.

35. Woś A., Tomczak F. (1983), Ekonomika rolnictwa. Zarys teorii, wyd.2, Wyd. PWRiL, Warszawa.

36. Woś A. (2000), Tworzenie i podział dochodów rolniczych. Dochody transferowe, IERiGŻ, Warszawa.

37. Woś A., Zegar J.S. (2002), Rolnictwo społecznie zrównoważone, IERiGŻ, Warszawa.

38. Zegar J.S. (2004), Dochody w strategii rozwoju rolnictwa (na progu integracji europejskiej), IERiGŻ, Warszawa.

39. Zegar J.S. (2012), Wspótczesne wyzwania rolnictwa, PWN, Warszawa. 